Artigos 


\title{
Ciclos de tempo \\ c indicadores de tempos na história da Amazônia
}

\author{
JÜRGEN HAFFER
}

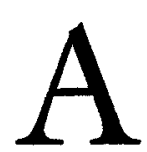

natureza da história tem sido encarada, tradicionalmente, como um composto de dois pontos de vista contrários, mas complementares. Em primeiro lugar a história refere-se a seqüências direcionais de eventos lineares não repetíveis, como por exemplo a formação de uma cadeia de montanhas ou a amplitude da vida de uma pessoa, do nascimento à morte - contingências complexas de séries de eventos ligados através do tempo. Em segundo lugar, as leis da natureza, imanentes e eternas, permitem uma compreensáo daqueles aspectos da história que são produtos de ciclos continuamente repetidos. Mares estão em incessante vaivém, florestas ex́pandem-se e se retraem, médias de temperatura e de umidade aumentam e diminuem. $O$ tempo não tem direção. Muitos estudiosos têm empregado as metáforas "indicadores de tempos" e "ciclos de tempo" a esses aspectos complementares, ambos necessários a uma compreensão abrangente da nossa própria história, da história da Terra e de seus animais e vegetais (Gould 1987).

Organismos e espécies seguem o indicador de tempo da genealogia ao longo de vias evolucionárias contingentes sem coalescência e seguem o ciclo de tempo quando linhagens de espécies separadas desenvolvem, independentemente, formas similares (análogas) de extremidades ou formas corpóreas para usos similares ou modos de vida baseados em princípios imanentes de função (tais como, por exemplo, formas corpóreas semelhantes de peixes e mamíferos nadadores oceânicos).

Examinarei, aqui, diversos aspectos da história da Amazônia e sua biota, aplicando a dicotomia de ciclo do tempo e indicador de tempo. Argumento, em particular, que a hierarquia dos ciclos ambientais perpétuos caracteriza a natureza da Amazônia, a partir de ciclos de curto prazo de queda de árvores e ciclos fluviais até ciclos paleoclimáticos de longo prazo. Esses ciclos contribuem para a heterogeneidade ambiental necessária para a manutençáo da elevada diversidade de espécies da Amazônia. Além disso, os ciclos paleoclimáticos funcionaram como efi- 
ciente "máquina de especiação" ou "bomba de espécies" durante o curso da história geológica.

Acompanhando a seta indicadora de evoluçáo através do tempo, esses últimos ciclos ajudam a explicar a origem da riqueza em espécies na Amazônia. Quando examino a fauna amazônica,não tenho em mente apenas insetos e outros grupos de invertebrados mas, principalmente, vertebrados como mamíferos, pássaros, répteis e anfíbios.

\section{Ciclos de Tempo}

Os ecólogos estudam cada vez mais as combinações hierárquicas distintivas dos ciclos de perturbação ambiental, respostas bióticas e padrões de vegetação em relação a micro, macro e megaescalas (Delcourt et al. 1983, Urban et al. 1987, Di Castri \& Hadley 1988, Pickett et al. 1989). Paisagens sáo mosaicos gerados por processos de perturbação que variam em escala, extensão, intervalo e intensidade de recorrência (Fig. 1). Processos bióticos também variam, de pequena escala, como o crescimento de um indivíduo animal ou vegetal até a reorganizaçâo de grupos de espécies. Fatores limitantes podem estar relacionados a condiçôes do solo e regimes climáticos. Ciclos diários de claro e escuro, bem

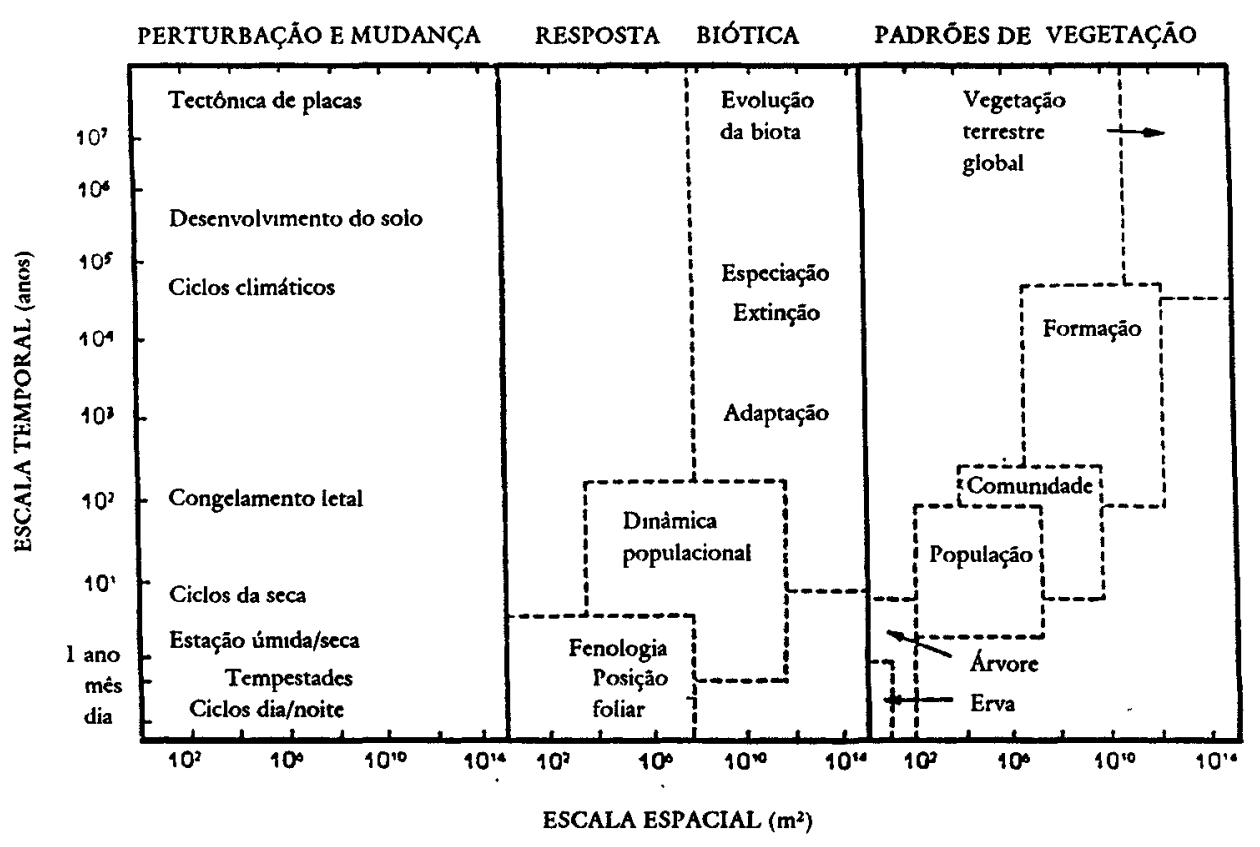

Fig. 1: Interrelação espacial e temporal de perturbações e alterações ambientais, resposta biótica e padróes de vegetação (seg. Delcourt et al. in Di Castri \& Radley 1988) 
como ciclos anuais de estaçóes secas a úmidas conduzindo, por exemplo, à elevação e abaixamento cíclicos do nível dos rios são eventos de alta frequiência e, como tais, parte dos ambientes abióticos de animais $\mathrm{e}$ vegetais.

Ciclos de perturbação afetando a vegetação da floresta pluvial compreendem, no extremo inferior da escala, à dinâmica da fase lacunar devida à queda de árvores ou deslizamentos locais, a níveis intermediários de dinâmica fluvial $e$, no extremo superior da escala, a ciclos climático-vegetacionais de baixa freqüência e ciclos tectônicos afetando a cobertura vegetal e os padróes de distribuição de animais numa escala regional (Haffer 1991). A duração do ciclo a cada nível nessa hierarquia varia, e ciclos individuais nâo são, necessariamente, de mesma duração. Cada processo em níveis superiores nessa hierarquia de perturbação sobrepóe-se a vários processos de níveis inferiores: a dinâmica da fase lacunar ocorre dentro de uma regiáo florestada afetada pela dinâmica fluvial; a própria região geral pode estar sujeita a efeitos climáticos. As dinâmicas paleoclimática e tectônica conduzem a mudanças na distribuição de vários tipos de vegetação de floresta e náo-floresta em regióes onde, numa escala geográfica menor, a dinâmica fluvial $\mathrm{e}$ a de fase lacunar regeneram continuamente a floresta. Os ciclos de perturbação hierárquica geram mosaicos cujas peças variam de tamanho e novas peças se sobrepóe continuamente às peças existentes.

Os processos locais de reposiçío causados por ciclos de perturbação rep:esentam ciclos de regeneração da floresta pluvial de curso livre. Eles são cíclicos no sentido de uma sequêencia repetitiva de mudanças.

\section{Teoria dos refúgios}

Estudos Avanfados tem a honra de publicar dois trabalhos de elevada interdisciplinaridade de autoria dos fundadores da chamada "Teoria dos refúgios". Uma rápida explicaçâo sobrc cles torna-se necessária. Desde os fins da década de 50, já se conhecia alguns fatos essenciais sobre as flutuações climáticas quaternárias que teriam afctado a dinâmica fitogeográfica do Brasil tropical atlântico. As descobertas fundamentais nessa direçāo ficam contabilizadas, em termos de história das ciências no País, aos trabalhos de André Cailleux e Jean Tricart.

Na década scguinte, trabalhando na Amazônia, Jürgen Haffer dedicou parte de seu tempo a observaçōes sobre os padróes de distribuiçáo de pássaros em diferentes quadrantes da regiāo. E, através da publicação de seu estudo "Speciation in Amazonian forest birds" (1969), detectou anomalias distributivas que somente poderiam ser explicadas por mudanças climáticas, suficientemente amplas para provocar retráçóes e re-cxpansōes de florestas no espaço total da Amazônia.

Ao mesmo tempo e convergentemente, Paulo Emílio Vanzolini atingiu depois de anos de estudos sobre distribuiçăo de lagartos na América Tropical a conclusóes que envolveram plenamente a idéia de refúgios, por ocasiăo de climas secos, no en- 
Todos os estágios dos ciclos de perturbaçio são transitórios, isto é, nenhum representa uma fase inicial ou final. Portanto, esses processos cíclicos são exemplos de "ciclos de tempo" sem componente de uma direção abrangente. Os vários processos de perturbação cíclica são examinados brevemente a seguir:

\subsection{Dinâmica da fase lacunar}

A regeneração cíclica da floresta pluvial devida à queda de árvores conduz a lacunas na floresta que podem ser causadas pela queda de uma única árvore ou de várias, em razão de senescência, parasitas ou doenças. Lacunas são também frequiêntemente causadas por deslizamentos locais em regiōes montanhosas, como por exemplo em seguida a um terremoto. De a $5 \%$ da floresta pluvial de terra firme são estimados como estando em estágios sucessivos seguindo quedas de árvores em lacunas (Hartshorne 1980). Quedas múltiplas de árvores, devidas, por exemplo, a ventanias, podem afetar grande porção de uma floresta. Taxas de reposição de florestas pluviais de terras baixas, devidas à dinâmica de fase lacunar, em diferentes localidades da Costa Rica, variam de 80 a 140 anos (Hartshorne 1978), indicando uma regeneração muito rápida da floresta pluvial.

A dinâmica de fase lacunar gera mosaicos móveis de pequena escala de segmentos de habitats diferentes nas florestas tropicais de terras baixas, como por exemplo, clareiras devidas a queda de árvores, invasão de ervas nas margens da floresta, vegetação pioneira densa e crescente vegetação florestal perfeitamente desenvolvida próxima às clareiras.

\subsection{Dinâmica fluvial}

A dinâmica fluvial afeta uma porção razoavelmente grande (20-40\%) da paisagem na Amazônia ocidental e também conduz à rápida alteraçáo da floresta nessa regiáo. As terras baixas amazônicas do leste peruano, por exemplo, consistem de um mosaico de habitats regionais de: (1) floresta de terra firme crescendo sobre velhas formaçóes fluviais (cerca de $70 \%$ da região), (2) florestas complexas, sobre antigas planícies de inundação não mais trabalhadas pelos rios (cerca de $15 \%$ ), e (3) floresta em planícies de inundaçáo ativa de rios modernos (cerca de $15 \%$ ), de acordo com estudos de Salo \& Kalliola (1989) e Salo \& Räsänen (1989). Os agentes da dinâmica fluvial são: migração de leito, desvio de leito e desvio de várzea, que sáo influenciados por atividades tectônicas frontais (foreland) ao longo da base da faixa da dobra dos Andes orientais (Räsänen et al 1987). Migraçáo de leito é causada por erosão fluvial lateral e conduz à sucessão primária sobre 
depósitos de restingas e coroas fluviais; desvio de leito devido à brusca mudança de setores do rio no interior da várzea (deriva de leitos) conduz à sucessão primária e secundária sobre vários tipos de depósitos de várzea; a planície de inundação inteira pode ser desviada devido a contínuos processos de assoreamento ou a movimentos tectônicos que conduzem a mudanças laterais graduais ou mais bruscas do rio junto com sua várzea. o tempo, durante o qual um ciclo se completa $\mathrm{e}$ o mesmo sítio dentro de uma várzea é novamente erodido por alteração no curso de rios, pode ser de algumas centenas de anos. Isso se deve à rápida erosão lateral de rios sinuosos próximos aos Andes, onde foram observados casos de $20 \mathrm{~m}$ e mesmo $250 \mathrm{~m}$ de erosăo de margens laterais em um ano (Salo et al. 1986). Reposições de sítios florestais na Amazônia devidas à dinâmica fluvial, fora de várzeas ativas, podem ser da ordem de 1.000 a 2.000 anos. Em contraste com a Amazônia superior, os leitos dos rios na Amazônia central são relativamente mais estáveis e as matas de várzea são controladas pelas inundaçóes anuais.

\subsection{Dinâmica climática}

Em regióes úmidas, com clima sazonal nítido, a floresta pode tornar-se muito seca próximo ao fim de uma estação anormalmente seca.

Grandes segmentos de floresta ou uma certa parte das espécies vegetais podem morrer ou secar em tal grau que chegam a queimar quando raios incendeiam a floresta (ou um veio de carvão, xisto betuminoso, etc. é exposto à superfície). $\mathrm{O}$ fogo pode ser considerado como um tremeio dos espaços intertropicais. Nesse sentido, sua monografia "Zoologia sistemática, geografia e a origem das espécics" (1970) representa um marco de interdisciplinaridadc.

Os trabalhos de Haffer c Vanzolini publicados nesta cdição tcm o valor de um duplo reconhecimento: a força da interdisciplinaridade cruzada com a persistência no aperfeççoamento de uma tcoria que há muito tempo já saiu do campo das hipótcses. Fm seu novo cstudo, Haffer demonstra o grau de atualização alcançado sobrc a bibliografia corrcnte $\mathrm{dc}$ geociências $\mathrm{c}$ biociências da Amazônia. Constitui, ainda, uma primcira c sutil resposta às críticas epidérmicas cndereçadas à "Tcoria dos refúgios". Atingc, por tim, uma séric de consideraçōes sobre as responsabilidades de nossa geração cm rclaçāo à prescrvação da biodivcrsidade, para todo o futuro do plancta Tcrra. Idćias que os cientistas brasilciros de há muito comungam. É confortável saber que por veredas entrecruzadas atingem-se conhecimentos de ponta, dotados de inusitada c estimulantes potencialidades. O sensível $\mathrm{e} \mathrm{bem} \mathrm{estudado} \mathrm{"Ai} \mathrm{de} \mathrm{ti,}$ Amazônia", de Gicrôncio Albuquerque Rocha, completa o quadro das contribuiçöcs que precederam, honram c perpassaram a Conferécucia do Rio de Janciro.

* Aziz $A b$ Sáber é prolessur visitante da Área de Ciências Ambientais do IEA c co-autor do Projcto likoram. 
distúrbio intermediário para florestas pluviais sazonais, nas quais incêndios limitados ocorrem de maneira repetida mas náo freqüiente e com baixa intensidade (Sanford et al. 1985, Goldammer \& Seibert 1989). Quando for encontrado carvão vegetal em associaçáo com artefatos de cerâmica, sua presença é comumente atribuída à ocupação humana. Todavia, carvāo vegetal também ocorre freqüentemente nos solos de florestas pluviais primárias que nunca foram queimadas pelo homem. A idade, em carbono radioativo, do carvão vegetal, existente sob vários tipos de floresta na regiăo de San Carlos, no sul da Venezuela, varia de $250 \pm 50$ anos A.P. a $6.260 \pm 110$ anos A.P. (Sanford et al. 1985; Saldarriaga \& West 1986) e sob uma floresta no Kalimantan oriental (Bornéu), de 350 a 17.510 anos A.P.(Goldammer \& Seibert 1989).

\subsection{Dinâmica paleoclimática}

Muitas áreas na regiáo neotropical rêm sido afetadas por mudanças ciclicas na vegetação durante o curso da história geológica. Durante os ciclos climáticos dos últimos 60 milhões de anos (períodos Terciário e Quaternário; era Cenozóica), a floresta pluvial úmida em muitas regiōes foi, provavelmente,substituída, repetidamente, por floresta aberta de palmeiras e floresta de lianas e, em algumas regióes até mesmo por savanas, antes que o ciclo da vegetação voltasse via floresta aberta à floresta pluvial úmida. Todavia, os dados básicos em apoio a essas assertivas são ainda escassos. Certas áreas da região neotropical foram, provavelmente, afetadas mais intensivamente do que outras, por essas mudanças vegetacionais, ou, por ocasiáo de ciclos particulares, onde a floresta pluvial foi mantida mais ou menos imutável durante uma fase seca particular ("refúgios florestais"). Em outras palavras, os ciclos vegetacionais paleoclimáticos seguiram vários "atalhos" em áreas diferentes e foram completos somente naquelas regióes onde a floresta pluvial foi substituída por vegetação não-florestal durante uma fase seca. Para ser exato, a floresta neotropical e a vegetação não-florestal são antigas, tendo se originado durante o Cretáceo e no início do Terciário. Em áreas de sua ocorrência ininterrupta, florestas e savanas ofereceram, continuamente, condiçóes ecologicamente estáveis e uniformes às espécies de animais tropicais. É a distribuiçáo geográfica abrangente desses tipos de vegetação que têm variado impressionantemente em resposta às mudanças climáticas mundiais da era Cenozóica. Os estudos geocientíficos revistos brevemente a seguir destruíram completamente a antiga noção dos trópicos como ambientalmente estáveis durante os tempos geológicos. 
Evidências obtidas de muitas regióes da América tropical indicam que alterações climático-vegetacionais extensivas ocorreram durante os últimos milhóes de anos (revisóes recentes incluem as de Ab'Saber 1982, Tricart 1985, Bigarella \& Ferreira 1985, Haffer 1987a, Schubert 1988, Hoppe \& Schobbinghaus 1991). Dentre os dados examinados nessas revisões há os seguintes: os sedimentos no Lago Valência, no norte da Venezuela, registram pelo menos quatro ciclos de enchimento e dessecaçâo do lago; campos de dunas nos lhanos do leste da Colômbia e sudoeste da Venezuela, ao norte da Amazônia, foram ativos durante o fim do Pleistoceno; flutuaçóes vegetacionais nessas regióes têm sido documentadas através de estudos de paleopolén. Observaçóes geomorfológicas extensivas indicam uma alteração de períodos climáticos úmidos e áridos também para as regióes norte, leste e central do Brasil, incluindo porçóes da Amazônia inferior, durante o Pleistoceno. $\mathrm{Na}$ última regiāo, Tricart (1974/1975), examinou a área geral de Santarém, na foz do Rio Tapajós e notou intensa dissecação da superfície do solo que teria ocorrido durante condições climáticas secas do passado geológico recente. Jornaux (1975), também concluiu que uma fase semiárida maior e relativamente longa, precedeu o período úmido presente.

Evidências geológicas e palinológicas adicionais, da ocorrência de períodos climáticos secos na região tropical da América do Sul, durante o Quaternário, e que resultaram no desaparecimento temporário de florestas densas das respectivas áreas de amostragem, foram coligidas, recentemente, no centro, sudoeste e sudeste da Amazônia (Fig. 2).

As florestas pluviais em Pitinga, a cerca de $250 \mathrm{~km}$ ao norte de Manaus (Fig. 2, no 4) têm camadas subjacentes de sedimentos variados, grosseiros e extremamente pobres que incluem camadas de fanglomerado associadas a depósitos pláceres ricos em ouro e estánho (Veiga et al. 1988: 166, Hoppe \& Schobbinghaus 1991: 1820). Tais sedimentos datam, provavelmente, do Pleistoceno médio e têm apreciável distribuiçáo lateral ao longo de um extensivo padrão de paleodrenagen. A natureza desses sedimentos clásticos indica que foram depositados sob condiçóes climáticas semi-áridas e na ausência de floresta pluvial densa na maior parte dessa regiáo. A mesma interpretação se aplica para a origem de outros depósitos pláceres na Amazônia brasileira tais como, por exemplo, na regiáo do Xingu, Teles Pires-Juruena, médio Tapajós e norte de Rondônia (Veiga et al. 1988, Bettencourt et al. 1988). Bibus (1983), também, relatou a ampla ocorrência na região do médio Rio Tapajós (Fig. 2, no 3) e nas baixadas ao redor da Serra do Cachimbo (Fig. 2, $\mathrm{n}^{\circ}$ 2) de detritos grosseiros na superfície de depressóes, acumulados durante um período de forte erosão quando o clima do fim do 


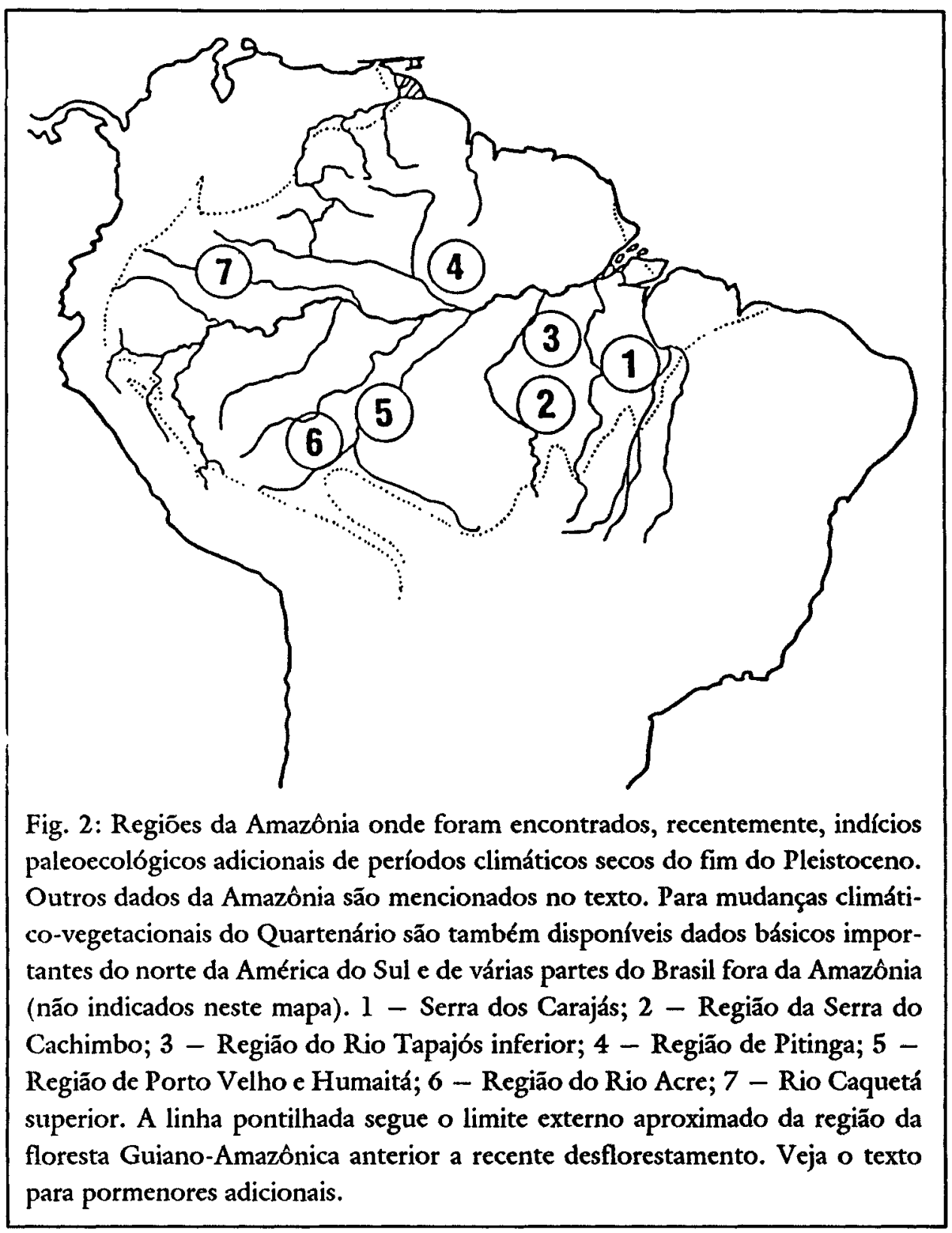

Quaternário era semi-árido e a vegetação da floresta pluvial tinha desaparecido largamente dessas regióes. Depois dessa fase, camadas arenosas cobriram a região toda sob um clima ainda mais seco (Bibus 1983). Observaçóes geomorfológicas de Emmerich (1988) em Rondônia (regióes de Porto Velho e Humaitá; Fig.2, no 5), também indicam um clima semi-árido e vegetação aberta nessa parte sul da Amazônia durante o fim do Terciário e fases climáticas áridas do Pleistoceno. Florestas voltaram a cobrir essas últimas regióes seguindo bacias e vales de rios. 
Através da sub-bacia do Acre (região superior do Rio Purús e inferior do Rio Acre; Fig.2, no 6), precipitados de gesso e aragonita, associados com sedimentos superficiais de granulação fina, indicam a dessecação de um extenso sistema fluvial-lacustre, devida a condiçốes climáticas áridas, há cerca de $\mathbf{5 3 . 0 0 0}$ anos, isto é, durante o último ciclo glacial (Kronberg et al. 1991).

As cimeiras relativamente planas e limitadas da Serra dos Carajás, no Pará (Fig. 2, nº 1), são cobertas por vegetaçáo aberta sobre canga $\mathrm{c}$ circundadas por todos os lados por florestas pluviais densas sob condiçóes climáticas vigentes.

Análises geológicas e de paleopolens de uma área nuclear coletados num brejo, existente num desses platôs, revelaram quatro períodos de regressão de floresta pluvial dessa região geral durante os últimos 60.000 anos (Absy et al. 1991). O conteúdo de pólen na superfície da área nuclear (representativa da situação presente) indica uma ampla floresta pluvial a despeito da ocorrência da vegetaçáo de canga ao redor do sítio de amostragem, mostrando, assim, a importância do perfil do pólen do core relativamente à vegetaçāo da regiáo geral e não apenas para a vegetaçāo local do próprio platô examinado. Na Amazônia superior ocorrem cascalhos em sedimentos de terraços no curso do Rio Caquetá, no sudeste da Colômbia (Fig. 2, no 7), os quais indicam condiçóes de assoreamento temporárias, mais torrenciais do que aquelas predominantes ao longo desse rio (Eden et al 1982).

Tais cascalhos podem ser interpretados como indicadores de fases periódicas de condiçóes áridas, ou, pelo menos, fortemente sazonais, na região de mananciais andinos. Isso não quer dizer, é claro, que todos os vales e várzeas dos maiores rios ou de muitos tributários menores da Amazônia, bem como de outras regiốes da América tropical afetadas por fases climáticas áridas do passado tenham provavelmente permanecido úmidos e extensivamente florestados, mesmo durante o pico de períodos secos. Tais habitats ribeirinhos podem, também, ter servido como refúgios florestais para certos elementos da mata, apesar de sua estreiteza e depleçáo geral de fauna (Meave et al. 1991).

Esses novos dados geocientíficos, resumidos acima, junto com os indícios de que já se dispunha, comprovam as amplas flutuaçóes climático-vegetacionais na Amazônia durante o Quaternário. Os dados vêm principalmente das regióes periféricas ao norte, sul e baixa Amazônia, embora a forte evidência de Pitinga e da regiáo do baixo Tapajós refira-se igualmente a porçôes da Amazônia central. Até o presente náo se dispóe de indicaçóes de fragmentação de floresta pluvial para a Ama- 
zônia superior; a acidentada regiáo fronteiriça entre o Brasil e o Peru (alto Purús e Rio Juruá) parece ser uma área particularmente promissora para estudos detalhados de campo a esse respeito.

Os dados geocientíficos disponíveis até agora são insuficientes para permitir o mapeamento das mudanças na distribuiçâo da vegetação da floresta e não-floresta durante os vários períodos climáticos $\mathrm{e}, \mathrm{em}$ particular, para o traçado da história e da exata localizaçáo de áreas de florestas e savanas residuais que, presumivelmente, serviram como refúgio para a flora e a fauna da Amazônia durante períodos climáticos adversos (veja Prance 1982, Prance \& Lovejoy 1985 e Whitmore \& Prance 1987, para análises sumárias acerca da possível localização dos refúgios de floresta e não-floresta na Amazônia durante o fim do Pleistoceno).

\subsection{Ciclos de Milankovitch}

A base astronômica das oscilaçốes climáticas tratadas acima são os ciclos de Milankovitch, assim chamados em homenagem ao astrônomo e matemático Milankovitch que primeiro se ocupou do assunto em 1930. Esses ciclos têm operado continuamente durante pelo menos uma porção principal da história da Terra (na medida em que se tornou conhecida nos últimos anos) e não apenas durante a Época Glacial dos últimos dois milhões de anos (Quaternário). Foram os causadores das oscilaçóes no nível do mar, alteraçóes rítmicas de facies dos estratos sedimentares do Mesozóico e Cenozóico e mudanças climático-vegetacionais nos continentes (Fischer 1981, Herbert \& Fischer 1986, Olsen 1986, Levinton 1988: 453, Bartlein \& Prentice 1989, Berger et al. 1989, Bennett 1990). Os ciclos de Milankovitch são devidos a processos celestiais com periodicidades de aproximadamente $20.000,44.000$, 100.000 e 400.000 anos e resultam de: (1) a variação da distância Terra-Sol devida a interaçóes gravitacionais da Terra com outros planetas e o Sol (ciclos de precessão; 23.000 e 19.000 anos), (2) o aumento e decréscimo da inclinação do equador na órbita da Terra ao redor do Sol (ciclos de obliquidade; 41.000 e 54.000 anos) e (3) a variação na forma da órbita da Terra ao redor do Sol (ciclos de excentricidade; 95.000, 123.000 e 413.000 anos). Essas oscilaçóes de curto prazo (alta frequiência) em termos geológicos, foram sobrepostas a uma tendência de resfriamento gradual do clima da Terra desde o início do Cenozóico, há cerca de 60 milhóes de anos, marcada por acentuados declínios ocasionais, como por exemplo, 37 milhōes e 2,5milhōes de anos atrás. O gradiente térmico latitudinal tornou-se alcantilado durante o curso do final do Terciário, quando as médias anuais de temperatura aumentaram nos 
trópicos e a temperatura de verāo decresceu nas altas latitudes. $O$ surgimento de camadas de gelo continentais no Quaternário está relacionado à configuração dos continentes e/ou formação de montanhas e acompanhou o crescimento das calotas de gelo nos pólos sul e norte, que se iniciou durante o Mioceno, há 15 e 6 milhóes de anos respectivamente.

Durante as oscilaçóes climáticas do Cenozóico (Terciário e Quaternário) causadas pelos ciclos de Milankovitch, as florestas nas latitudes temperadas e tropicais sobreviveram a fases secas em áreas remanescentes (fragmentos florestais ou "refúgios") e reexpandiram-se durante períodos úmidos, quando, reciprocamente, a vegetação não-florestal aberta era mais limitada em extensáo. É provável que tenha ocorrido uma redução de $50 \%$ na massa de árvores florestais durante os períodos frio-secos do Pleistoceno (Livingstone 1980). Os remanescentes de uma zona de vegetação tropical durante um período climático adverso representaram, provavelmente, todas situaçōes intermediárias, desde grandes e extensos blocos a pequenos e dispersos sítios em "mini-refúgios" localizados onde condiçóes favoráveis permitiram a existência continuada das respectivas biotas ou porçóes de biotas. Pormenores permanecem desconhecidos.

\section{Indicadores de Tempos}

\subsection{História e evolução geológica}

A continuada sedimentaçâo diferencial da bacia da Amazônia central durante as eras Mesozóica e Cenozóica seguiu o indicador de tempos. As regióes de velhas terras do escudo guianense ao norte do rio Amazonas e do escudo brasileiro ao sul foram gradualmente levantadas durante esses períodos. Do fim do Mioceno (final do Terciário) progressivamente, e em resposta aos primórdios da elevaçáo dos Andes no oeste, o rio Amazonas começou a construir um grande delta no oceano Atlântico, por sobre e além de uma antiga plataforma de carbonato. A elevação andina continuou através do Plioceno (e ainda continua na época atual) conduzindo à emergência das terras baixas da Amazônia superior e ao estabelecimento do padrão de drenagem dirigido para o leste na Amazônia. As chapadas residuais (tepuis) da região fronteiriça ao sul da Venezuela e extremo norte do Brasil, formavam, originalmente, um contínuo platô elevado de arenito, o qual, crescentemente, foi dissecado pela erosão durante os últimos $\mathbf{6 0}$ milhóes de anos (período Terciário). Estudos geomorfológicos podem eventualmente permitir a 
determinaçāo da sequiência hierárquica da dissecação dessa páleo-chapada, hoje desfeita em remanescentes de erosão, muito limitados. De modo geral, os processos geológicos acima, aqui interpretados direcionalmente, também podem ser vistos como parte de um ciclo principal de elevação e intemperismo gradual e eventual desaparecimento de todo um continente.

Processos geológicos direcionais e as consequiências dos ciclos de Milankovitch determinaram um efeito extremamente importante dos indicadores de tempos (Fig. 3): diferênciação orgânica e evolução, isto é, especiação e divergência. Os eventos razoavelmente bem conhecidos para a escala de 20.000 a 100.000 anos durante o Quaternáiio, especialmente com respeito à ruptura das comunidades animais e vegetais, têm sido um fator permanente durante a história da Terra (veja acima), embora, possivelmente, de amplitude inferior durante o período préQuaternário e geralmente náo reconhecido por causa da análise grosseira da maior parte dos registros paleontológicos (Bennett 1990, Terborgh 1992). Na medida em que o clima mudou, em resposta aos ciclos de Milankovitch, as comunidades dispersaram-se e novas comunidades desenvolveram-se sob condiçóes ambientais alteradas. Ditribuiçáo de espécies, composição de comunidades locais e situaçóes competitivas mudaram à medida que espécies se ajustaram a condiçóes diferentes; novas adaptaçóes acumularam-se sob um novo regime. Os ciclos de Milankovitch levaram à alternância cíclica entre continuidade de habitat (quando as distâncias distribucionais da espécie animal respectiva eram mais ou menos extensivas) e descontinuidade de habitat (quando as distâncias de espécies estreitamente adaptadas eram fragmentadas). Dessa maneira, variaçóes cíclicas orbitais supriram as condiçóes necessárias para que ocorressem a especiação geográfica (Mayr 1942, 1963) e a rápida divergência evolucionária em populaçóes comparativamente restritas de animais e vegetais durante períodos de fragmentação dos habitats. Esses processos evolutivos são efeitos dos indicadores de tempos que colocam os processos ambientais abióticos cíclicos (analisados acima) num contexto direcional. Espécies animais e vegetais, uma vez diferenciadas em um dos fragmentos de habitat (refúgios), podem ter seguido a movimentaçáo dos habitats durante os ciclos vegetacionais subseqüentes, uma vez que as duraçóes de espécies são usualmente mais longas do que os ciclos individuais de Milankovitch.

Durante sucessivos períodos climáticos secos do fim do Cenozóico (fim do Terciário-Quaternário), alguns dos maiores refúgios florestais da Amazônia situaram-se, provavelmente, em áreas correspondentes em torno de relevos pré-existentes (ao longo da base oriental dos Andes, 


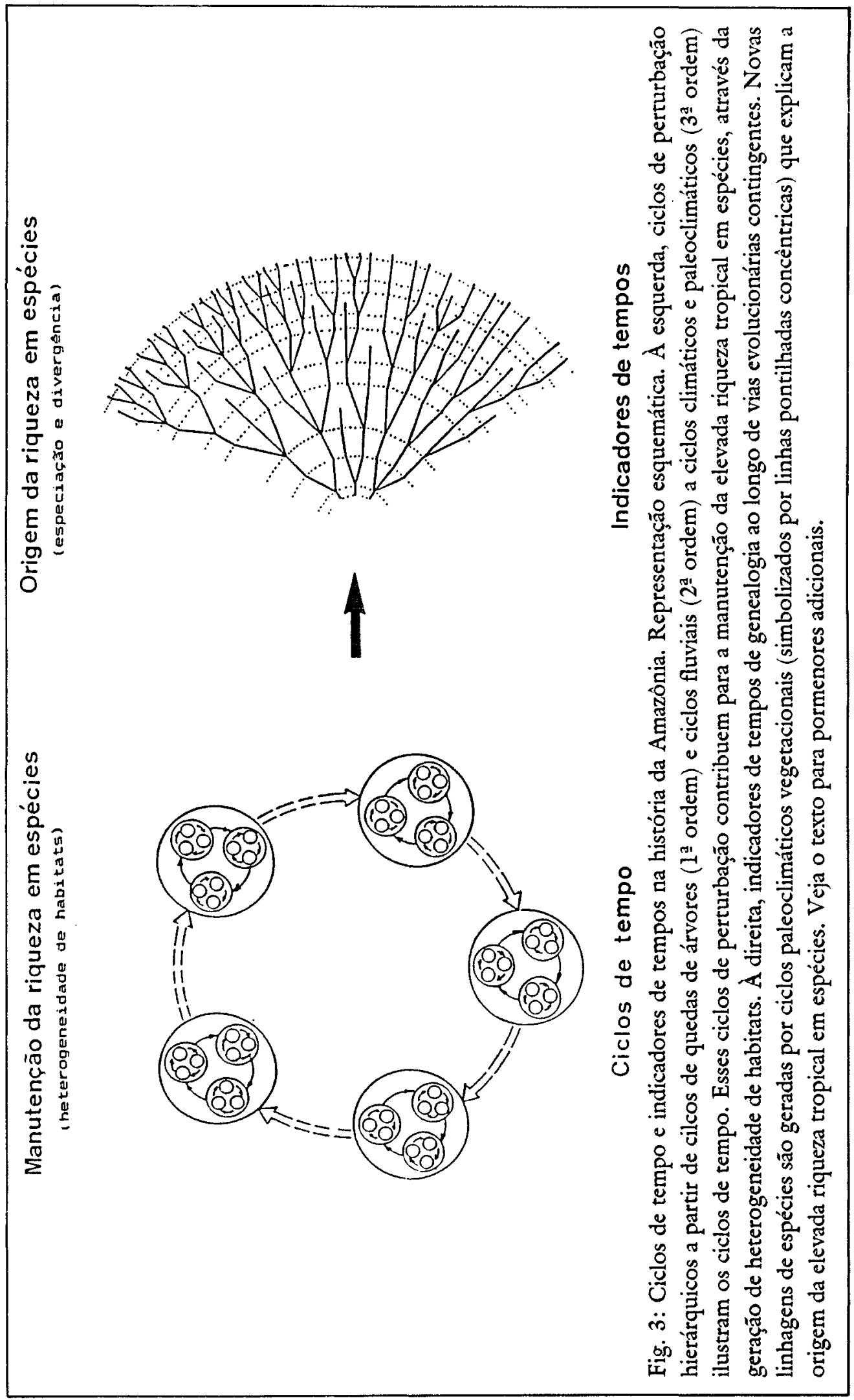

Estudos Avançados, 6(15), 1992 
ao redor das montanhas das Guianas - sul da Venezuela e aqueles do Brasil central). Isso pode ter levado a uma diferenciação adicional das populações dos refúgios, as quais, após terem iniciado o processo de diferenciação durante um primeiro ciclo, continuaram esse processo durante um ou mais dos períodos seguintes de isolamento geográfico ("efeito de ressonância", Vanzolini 1973) até que eventualmente atingiram status de espécie e foram capazes de dispersar-se através de regióes maiores da Amazônia. É óbvio que em muitos grupos de organismos as populaçôes que passaram por diferenciação não atingiram status de espécie durante um ou dois dos ciclos de Milankovitch de rápida sucessão, mas somente através do efeito adicional de vários desses ciclos e que as espécies, uma vez formadas, sobreviveram a muitos ciclos climático-vegetacionais. $\mathrm{O}$ tempo necessário para o processo de especiação varia amplamente entre animais e vegetais, não levando em consideração fatores tais como o tamanho da população do refúgio ou a duraçáo de um período particular de isolamento geográfico.

A teoria dos refúgios como foi proposta para a América tropical por Haffer $(1969,1974)$ e Vanzolini $(1970,1973$; Vanzolini \& Williams 1970) enfatiza a multiplicação, extinção e migração de espécies animais em pulsações, em resposta às mudanças climático-vegetacionais da Terra, antecipando, assim, diversos aspectos da hipótese de alteração por pulsação (Vrba 1985), que também se baseia no reconhecimento de alteração faunística por pulsaçóes, quase simultâneamente através de diversos grupos de animais, e em previsível sincronia com mudanças no ambiente físico. Originalmente a teoria dos refúgios aplicada à biota das zonas tropical e temperada foi admitida como referindo-se apenas ao Plcistoceno. Entretanto, com o reconhecimento de que os ciclos de Milankovitch influenciaram o clima durante a maior parte da história da Terra, a teoria dos refúgios é aplicável à diferenciação biótica, especialmente no domínio terrestre, durante o Terciário e o Mesozóico.

\subsection{Consideraçốes recentes acerca da teoria dos refúgios da Amazônia}

Populaçóes vegetais e animais, ecologicamente especializadas, com reduzidas necessidades de habitat, que ficaram isoladas nos refúgios florestais e não-florestais durante fases climáticas adversas, tornaram-se extintas, sobreviveram sem muita alteraçáo ou diferenciaram-se até nível taxionômico de subespécies ou espécies antes de entrar em contacto secundário, principalmente em áreas entre os refúgios, com populações da mesma espécie de outros refúgios durante uma fase sucessiva, favorável e ampla. Em vista de muitas evidências geocientíficas gerais e im- 
portantes (revistas acima), diversos autores consideraram a teoria dos refúgios favoravelmente ao interpretarem seus próprios resultados de pesquisas sistemáticas e biogeográficas nos neotrópicos, como por exemplo os colaboradores de várias obras recentes de múltipla autoria (Prance 1982, Prance \& Lovejoy 1985, Whitmore \& Prance 1987); veja também a discussão geral recente por Terborgh (1992) e a revisão dos refúgios florestais da planície tropical na ãfrica central por Colyn et al. (1991).

Desconsiderando a maioria das evidências geocientíficas, outros autores têm questionado a extensiva retração e possível fragmentação das florestas amazônicas durante períodos climáticos secos. Além disso eles deturparam certos aspectos do conceito de refúgio em suas revisóes, dirigindo dessa maneira seus comentários a caricaturas distorcidas dessa teoria. Podemos citar os seguintes exemplos:

- Connor (1986) e Salo (1987) enfatizaram a "circularidade"do conceito de refúgio tendo os mesmos dados sido supostamente usados tanto na geráção quanto na corroboraçáo da hipótese. Na realidade, a sugestão original para a possível localização dos refúgios florestais na América tropical baseou-se no padrão de precipitação pluviométrica regional comum e em consideraçóes do relevo superficial junto com outras evidências geocientíficas (Haffer 1969). Independentemente, os padróes de distribuição biótica sugeriram um conjunto de áreas nucleares (áreas de endemismo) para organismos florestais (Simpson \& Haffer 1978). Uma comparação desses dois conjuntos de áreas, derivados independentemente, mostrou que eles sáo em grande parte, coincidentes, o que sugere que as mudanças climáticas e a formação de enclaves florestais foram, provavelmente, a causa dos padróes de distribuição e diferenciação considerados.

- Lynch (1988: 320) e Gentry (1989: 123) representaram o conceito de refúgio como referente a um único e geologicamente recente evento de vicariância. Na realidade, uma série de reversóes climático-vegetacionais e eventos vicariantes associados, ocorridos durante o Pleistoceno (e o período Terciário precedente), serviram como hipótese para a causa da diferenciação de taxa.

- Diferenciação evolucionária complexa de faunas e eventos de especiação ocorreram durante o Terciário devidos a mudanças paleográficas e climáticas e antecederam os eventos de especiação do Pleistoceno (Simpson \& Haffer 1978: 512, Haffer 1985: 137, 1987b: 147). Autor algum jamais afirmou (como Cracraft \& Prum 1988: 603 criticaram) "... que a diversificação da biota neotropical é principalmente o resul- 
tado de ... isolamento dentro de refúgios florestais Quaternários." $\mathrm{O}$ conceito de refúgios do Pleistoceno está relacionado, principalmente, com situação taxionômica inferior e padróes de diferenciação geologicamente recente, e em conseqüência, refere-se principalmente, ao capítulo mais recente na história da biota neotropical.

- Connor (1988: 1027) assegurou que eu havia proposto: "... os limites das distribuiçóes de espécies existentes hoje na Amazônia estariam fora de áreas admitidas como tendo sido refúgios florestais durante o Pleistoceno". Entretanto, o que eu havia proposto era que zonas de contacto secundário entre subespécies bem diferenciadas e espécies parapátricas estâo agrupadas, principalmente, em áreas entre os centros de endemismo (refúgios presumidos).

- A descoberta de Colinvaux (1987) de que a floresta na escarpa oriental dos Andes equatorianos, a uma altitude de $1.100 \mathrm{~m}$, durante o último período glacial era uma floresta úmida com elementos andinos é interessante, mas em vista da altitude da localização do exemplo, próximo a Mera, e de dados anteriores da Colômbia, deixa de ser surpreendente. Em virtude do elevado gradiente de temperatura vertical nas montanhas tropicais durante períodos glaciais, pode ter sido possível para os elementos da floresta andina subtropical existir em altitudes mesmo inferiores a $1.100 \mathrm{~m}$, durante períodos frios, quando, ao mesmo tempo, a floresta amazônica de terras baixas estava espalhada ao longo da base adjacente dos Andes, abaixo de $500 \mathrm{~m}$ de altitude (onde se admite ter existido o refúgio da floresta Napo). Parece que as conclusóes de Mera náo podem ser tomadas diretamente como desmentindo (como afirmou Colinvaux) a previsão da hipótese de refúgios, de que uma extensiva floresta amazônica existiu na base oriental dos Andes equatorianos durante períodos climáticos áridos do Pleistoceno. Colinvaux (l.c.) sugeriu resfriamento ao invés de aridez, como sendo a resposta geral do clima na bacia amazônica à glaciação setentrional.

Cracraft \& Prum (1988) enfatizaram o efeito das mudanças paleogeográficas do Terciário na explicação da origem de muitas espécies de pássaros neotropicais viventes e seus padrôes de distribuição, embora tenham admitido (1988: 617): "A hipótese de refúgios permanece como explicação viável para os padróes de vicariância documentados" (em muitos grupos de pássaros florestais). Em vista de discussóes anteriores (e.g. Simpson \& Haffer 1978: 512) e de evidência mais recente para as oscilaçóes climático-vegetacionais do pré-Pleistoceno (veja acima), considero-me incapaz de compreender a assertiva feita por Cracraft \& Prum (1988: 616) de que " uma idade do Pleistoceno para a maioria dos taxa, 
em nível de espécie, na biota amazônica ... é uma conseqiiência lógica e componente crítico da hipótese dos refúgios." Visto que os ciclos de Milankovitch são agora admitidos como tendo operado igualmente (conduzindo à formação de refúgios) durante períodos do pré-Pleistoceno, tal argumento é inaceitável. A teoria dos refúgios refere-se a postulada origem de espécies em refúgios ecológicos independente da fase do período. Atualmente, técnicas moleculares, não são suficientemente refinadas para determinar a idade das linhagens de espécics viventes e distinguir entre a diferenciação do Pleistoceno e pré-Pleistoceno. Räsänen et al. (1987) sugeriram inundação regional temporária das porçóes centrais das bacias sub-andinas na Amazônia superior, que presumivelmente isolou populações animais nas áreas intercalares de terras altas (arcos geológicos), na parte oriental do Equador e do Peru, durante vários períodos geológicos.

Entre os autores recentes, partidários da teoria fluvial como uma interpretaçāo da diferenciação regional da biota amazônica, estão Hershkovitz (1969, 1977), Salo (1987) e Capparella (1988). Segundo essa interpretação, populaçóes animais e vegetais na Amazônia separaram-se pelo desenvolvimento do sistema fluvial, os leitos dos rios e suas várzeas atuando como barreiras à dispersão. $O$ efeito das alteraçóes fluviodinâmicas sobre o processo de especiação em vertebrados ainda não está resolvido. Muitas populaçóes separadas por rios largos são, naturalmente, bem diferenciadas. Entretanto essas diferenças genéticomorfológicas conspícuas de populaçóes de pássaros e mamíferos, freqüentemente desaparecem de forma clinal próximo às regióes das nascentes, onde as populaçóes respectivas são largamente contínuas, uma vez que os rios sáo estreitos e deixam de ser barreiras. Os autores que dão ênfase ao modelo de especiação fluvial usualmente não discutem diversas dificuldades com esse modelo, tais como, por exemplo, a falta de isolamento geográfico de populações nas regióes de nascentes de rios; a transferência freqüente de uma extensiva porção de terra para o lado oposto de um rio cada vez que uma alça de meandro é interrompida (dessa maneira, mesmo organismos de dispersão reduzidas são rotineiramente "transportados" passivamente, inclusive através de rios caudalosos); a ocorrência de numerosas zonas de contacto entre subespécies e espécies de pássaros na Amazônia, em regiōes florestais de terra firme ecologicamente uniformes (seus sítios, em muitos casos, náo estáo relacionados com rios grandes); o problema de especiação em pássaros de dossel de vôo vigoroso que facilmente atravessam rios largos; e a diferenciação de espécies que habitam zonas de vegetação criadas por rios. Em geral, parece que os rios sáo superestimados como barreiras à dis- 
persāo de animais sedentários (os quais podem ultrapassar uma barreira fluvial na regiáo da cabeceira, atravessar o rio em algum tipo de balsa, ou ser transportados passivamente ao outro lado do rio quando uma alça de meandro for interrompida).

A teoria do refúgio fluvial combina aspectos da teoria fluvial com a de refúgios de diferenciação faunística. Populaçóes animais têm sido presumivelmente isoladas em "semi-refúgios" separados por uma combinação de rios amplos (acrescidos de suas várzeas) e por extenso terreno ecologicamente impróprio nas regióes das cabeceiras que perderam as florestas em períodos climáticos secos. Se essa interpretação fosse examinada segundo a teoria fluvial, para cujo modelo as mudanças climático-vegetacionais da Amazônia não são decisivas, o argumento ficaria confuso.

A parte central do vale amazônico foi convertida numa regiáo de extensivas lagoas e lagos, quando o nível do mar elevou-se a $50 \mathrm{~m}$ acima do nível oceânico corrente durante os períodos interglaciais do Pleistoceno. A sugestão recente de que toda a Amazônia central foi ocupada por um grande lago, cujo nível elevou-se a cerca de $200 \mathrm{~m}$ acima do nível oceânico atual, durante o fim do Quaternário (Frailey et al. 1988), permanece especulativa até que diversas dificuldades desse modelo sejam resolvidas: o mesmo estrato sedimentário no sudoeste da Amazônia, que Frailey et al. (l.c.) interpretaram como depósitos lacustres, são considerados indicativos de um ambiente fluvial por Räsänen et al. (1987). Ademais, a natureza da suposta zona de barreira, próxima à desembocadura do rio Amazonas, capaz de reter o "Lago Amazonas" a um nível de superfície cerca de $200 \mathrm{~m}$ acima do nível oceânico presente é inteiramente desconhecida.

\subsection{Conceituação da teoria dos refúgios na Amazônia}

Durante a primeira metade deste século náo havia modelos unificados para o estudo da paisagem amazônica e sua biota. Presume-se que a vasta bacia sedimentária da Amazônia tenha sido preenchida gradualmente, durante os últimos estágios de sua longa história geológica, com sedimentos límnicos, fluviais e continentais dos períodos Terciário e Quaternário (Harrington 1962). Supõe-se que a região toda tenha sido pouco afetada por flutuaçóes climático-vegetacionais que influenciaram latitudes superiores do mundo durante os últimos dez milhóes de anos (Terciário e Quaternário). Implicitamente, a idade, os padróes de adaptaçóes e distribuição de organismos da Amazônia e da biota tropical foram admitidos geralmente como tendo se originado durante o curso 
do período Terciário e, em qualquer caso, foram imaginados como sendo muito mais velhos do que aqueles das floras $\mathrm{e}$ faunas das zonas temperadas do norte e do sul. Agentes de diferenciação biótica sugeridos foram mudanças paleogeográficas na distribuição de terra e mar, bem como o desenvolvimento do sistema fluvial amazônico.

A proposta da teoria dos refúgios para a América tropical (Haffer 1967a, 1969, 1974; Vanzolini 1970, 1973; Vanzolini \& Williams 1970; Müller 1973) desafiou várias posiçóes anteriores defendidas por muitos pesquisadores a respeito de uma admitida estabilidade ambiental dos trópicos e uma supostamente velha idade geológica da maioria ou de todas as espécies da fauna amazônica. Em atenção a pedidos, incluo aqui alguns comentários acerca das consideraçóes que me levaram a propor o conceito de refúgio 25 anos atrás. Comecei a aplicar esse modelo à biota tropical americana durante meados da década de 60 , baseado nos resultados de pesquisas geológicas e ornitológicas de campo em viagens que fiz na Colômbia, Venezuela, Peru e Bolívia entre 1957 e 1967. Minha formação como geólogo e paleontólogo foi obtida na Alemanha. Ao mesmo tempo, tornei-me um ornintólogo amador. Acompanhara a literatura sobre a história do Pleistoceno da biota Paleártica e de diversas zonas de contacto de taxa intimamente relacionados de pássaros no norte da Alemanha, onde se hibridam como subespécies (e.g. Corpus c. corone/ C. c. cornix) ou se excluem geograficamente como espécies sem hibridação, na estreita zona de sobreposição (e.g. Luscinia luscinia/ $L$. megarbynchos). Em 1957 aceitei o oferecimento de uma companhia internacional de petróleo para conduzir pesquisas geológicas de campo na Colômbia, o que me daria a oportunidade de tornar-me familiarizado com uma fauna tropical. Durante diversos anos de pesquisas geológicas de campo, em lombo de mula e em canoas nas florestas e savanas das terras baixas tropicais da Colômbia, estudei os estratos geológicos e sua história estrutural durante o período Terciário, quando se originaram os Andes setentrionais. Ao mesmo tempo coletei espécimes de pássaros numa base seletiva, concentrando-me naquelas espécies que apresentavam certos problemas taxionômicos ou biogeográficos, como ficou determinado através de estudos em literatura relevante.

De maneira geral, esperava encontrar certa congruência de direçáo e extensão das estruturas geológicas (e.g. zonas de elevação e sedimentação) com as características biogeográficas mapeadas nessa região, porque admiti uma idade comparável das estruturas geológicas e dos padróes biogeográficos. Em outras palavras, esperava ser capaz de correlacionar, de maneira aproximada, as séries de distribuiçáo de espécies de pássaros florestais e a localização das zonas de contacto entre subespé- 
cies e espécies representativas no noroeste da Colômbia com certas características geológicas naquela região. Entretanto, isso era apenas parte do problema. Como exemplo, as estruturas geológicas levantadas no Terciário, ao longo de ambos os lados do Vale Atrato inferior, no noroeste da Colômbia, continuam sem qualquer interrupção geológica até o leste do Panamá; tais estruturas são cobertas em ambas regióes com um manto de florestas tropicais. Por outro lado, certo número de tixa de pássaros intimamente relacionados, mas com diferenças pronunciadas, habitam as florestas ao longo das partes panamenhas e colombianas dessas cadeias de montanhas. A noroeste da Colômbia e próximo à fronteira do Panamá, esses pássaros diferentes excluem-se mutuamente, de maneira abrupta, ao longo de zonas de contacto nítidas que representam zonas principais de descontinuidade biogeográfica (Haffer $1967 a, b)$ e que cruzam as estruturas geológicas em ângulo reto.

Essa situação de formas geológicas uniformemente florestadas e estruturalmente contínuas sendo ocupadas, nas porçóes panamenhas e colombianas, por membros de diferentes faunas florestais não permitiu estabelecer-se a correlação da origem das estruturas geológicas (do período Terciário) com o desenvolvimento dos padróes de distribuição desses pássaros representativos. Por outro lado, indicações para flutuaçóes climático-vegetacionais durante o Quaternário na Colômbia (como se divulgava com base em estudos de paleopólen por T. van der Hammen dos Serviços Geológicos de Bogotá, Colômbia, durante os anos 60) parecem fornecer uma resposta ao problema da origem de alguns dos padróes biogeográficos de distribuiçáo e diferenciação de aves a nível de subespécies e expécies, em particular as razoavelmete numerosas zonas secundárias de contacto de bandos de pássaros no noroeste da Colômbia. Esse conjunto de zonas de contacto localiza-se entre dois centros de endemismo de fauna, respectivamente na América Central e na região de Chocó, no oeste da Colômbia (Haffer 1967a, b). Possivelmente, florestas abertas ou mesmo vegetação não-florestal substituíram, repetidamente, as atuais florestas semi-sempre-verdes nas regióes de terras baixas do noroeste da Colômbia e do leste do Panamá durante diversas fases climáticas secas do Pleistoceno, isto é, durante os últimos dois milhões de anos (e após a formação das estruturas geológicas nessa regiāo), quando florestas úmidas de terras baixas retraíram-se para áreas de precipitação particularmente elevada, tais como ao redor das cadeias de mais altas montanhas na Meso-América e na região de Chocó, do oeste da Colômbia.

Dessa forma, uma fauna de floresta densa na Meso-América pode ter sido separada repetidamente de uma fauna florestal do oeste da 
Colômbia, levando à diferenciação de certo número de subespécies e espécies componentes durante períodos de isolamento geográfico. Presumivelmente, florestas separadas reuníram-se, formando novamente uma zona de floresta contínua desde a regiáo de Chocó, através das terras baixas do noroeste colombiano, até a Meso-América, durante fases climáticas úmidas tais como no presente. Sob esse modelo, os pássaros florestais endêmicos representativos da América Central e oeste colombiano seguiram sua expansiva zona de habitat e reuníram-se no noroeste da Colômbia, ao longo das zonas de contacto, como estão mapeadas hoje. Considero esta uma interpretação plausível, embora não existam dados palinológicos do Quaternário da própria regiăo do Rio Atrato inferior disponíveis para corroborar esse modelo (mas apenas de outras partes do norte e leste colombiano). A fim de testar a validade regional dessa hipótese relativa às mudanças climático-vegetacionais e seus efeitos biogeográficos na América tropical, apliquei esse modelo, numa etapa seguinte, para a Amazônia e sua avifauna. Os componentes básicos do modelo amazônico (Haffer 1969) foram: (a) zonas de altas precipitaçóes pluviométricas na parte central da América do Sul, como é determinado, pelo menos em parte, pelo relevo superficial (e.g. próximo à base oriental dos Andes, ao redor das chapadas do sul da Venezula, à base nordeste das montanhas no interior das Guianas e ao longo da base norte das chapadas do Brasil central), bem como (b) os resultados de observaçóes geomorfológicas, por diversos autores, no sul da Venezuela, Amazônia inferior, Brasil central e leste do Peru, indicando de um modo geral, e, provavelmente, que durante o Quaternário, condiçôes climáticas mais secas do que as atuais prevaleceram repetidamente sobre grandes partes da Amazônia. Estudos palinológicos do norte da América do Sul ( $T$. van der Hammen e colaboradores) também revelaram repetidas alteraçóes vegetacionais sobre certas áreas durante o Quaternário. As interessantes consideraçóes feitas por Vanzolini (1967) e Vanzolini \& Ab'Saber (1968), quanto ao provável efeito de tais flutuaçóes climático-vegetacionais sobre as faunas da Amazônia e do sudeste brasileiro, respectivamente, estimularam meus próprios estudos biogeográficos de diversos grupos de pássaros amazônicos, em particular o mapeamento de regióes onde espécies endêmicas com distribuição restrita de grupos em "áreas de endemismo" (áreas nucleares ou centros de distribuição) e de zonas de contacto secundário entre pares de membros de espécies e subespécies que são encontrados, principalmente, em regióes entre as áreas de endemismo. Uma comparação dos dois conjuntos, derivados independentemente, de áreas na Amazônia (de alta precipitação pluviométrica e de endemismo de espécies), mostrou que são em grande parte, coincidentes, o que sugeriu que as mudanças cli- 
máticas e a formação de presumíveis regiōes florestais isoladas (refúgios), foram provavelmente, a causa dos padróes de distribuição e diferenciação de aves observados (Haffer 1969, 1974). Independentemente e ao mesmo tempo, Vanzolini $(1970,1973$; Vanzolini \& Williams 1970) chegaram a conclusóes idênticas a respeito do significado biogeográfico das flutuaçóes climático-vegetacionais na América tropical, usando materiais e métodos diferentes. Esses herpetólogos encontraram áreas nucleares de expressão uniforme de caracteres no lagarto Anolis chrysolepis, separadas por regióes onde variaçăo complexa dos caracteres sugere hibridaçáo e introgressão ao longo de zonas de contacto sencundário.

\section{Riqueza em espécies de pássaros na Amazônia}

Estudiosos da diversidade biológica nos trópicos reconhecem as seguintes questóes e problemas relacionados: (1) Quais sáo os padróes regionais de variação na riqueza em espécies? Aspectos geográficos da riqueza em espécies. (2) Como "funcionam" as comunidades tropicais ricas em espécies? Esta questão refere-se a aspectos ecológicos da riqueza em espécies, em particular aos mecanismos de coexistência de numerosas espécies, isto é, à manutênção da elevada riqueza tropical em espécies. (3) Por que os números de espécies são tão mais elevados nas faunas tropicais quando comparados aos das faunas de zona temperada? Aspectos. histótico-evolucionários da riqueza em espécies: a origem da elevada riqueza tropical em espécies.

\subsection{Aspectos geográficos regionais}

A riqueza local em espécies de pássaros que envolve todos os tipos de floresta é bastante alta no extremo oeste da Amazônia (superior a $\mathbf{5 0 0}$ espécies) e declina com o aumento da distância dos Andes (Haffer 1990). Riqueza muito elevada (400-500 espécies) caracteriza avifaunas locais das florestas que se estendem da Amazônia supcrior em direção ao extremo leste, nas regióes montanhosas ao norte e sul da parte central do vale amazônico (onde a riqueza em espécies é um pouco reduzida, ocorrendo menos de 400 espécies em sítios separados). Esse padrão regional geográfico pode refletir a situação ecológica global de solos pobres em nutrientes na regiáo da Amazônia central, cercada ao norte, sul e oeste por extensivos distritos compostos por áreas colinosas a montanhosas. Aqui os solos são um pouco mais ricos em nutrientes, podendo presumir-se, então, que mantenham faunas e floras correspondentemente mais ricas, especialmente no extremo oeste próximo aos 
Andes, onde magnificentes florestas de várzeas sobre ricos solos aluviais sâo muito difundidas. Florestas da Amazônia superior geralmente exibem a flora e a fauna mais diferenciadas do mundo (Gentry 1988). Os dados de pássaros sáo comparáveis aos dos padróes geográficos de riqueza de espécies em árvores, borboletas, répteis e anfíbios.

Um número razoavelmente grande de espécies endêmicas de pássaros habita pequenas áreas geográficas, seus centros de origem agrupam-se em diversas, ao invés de reduzidas, regiōes da Amazônia (áreas de endemismo designadas por Haffer, 1969: Napo, Inambarí, Imerí, Rondônia, Guiana e Belém). Enquanto as consideraçóes ecológicas do meio ambiente amazônico atual podem explicar os padróes regionais da riqueza em espécies de aves, as espécies de pássaros caracterizando as áreas de endemismo podem ter se originado devido às vicissitudes da história geológica da região amazônica durante o Cenozóico (Terciário-Quaternário) e antes.

\subsection{Manutenção da riqueza em espécies}

A complexa estrutura da floresta pluvial e a enorme diversidade de espécies vegetais sob um clima tropical permitem a coexistência de grande número de espécies animais nos sítios florestais locais, através de reduzida especialização ecológica. Além disso, a dinâmica da fase lacunar e a dinâmica fluvial geram continuamente heterogeneidade de habitat em larga escala (veja acima). Dessa maneira esses ciclos de perturbação contribuem efetivamente para a manutenção da riqueza em espécies tropicais. Muitas cspécies animais que habitam a floresta pluvial são amplamente distribuídas, geográfica e ecológicamente, ocupando uma variedade de habitats, ao passo que outras espécies são mais especializadas ecologicamente e ocorrem apenas em certas manchas de microhabitat, tais como, por exemplo, na copa de um emaranhado de trepadeira, em sítios de clareiras ou em faixas de determinada vegetação ao longo de cursos d'água florestais. A dinâmica da fase lacunar pode suprir suficiente separação espacial no caso de populaçóes de pequenos invertebrados para que ocorra diferenciação de subespécies ou espécies. Esse, entretanto, não é o caso de animais vertebrados. Muitos destes são especificamente adaptados à ocorrência de mancha de seus habitats particulares na floresta pluvial ou áreas de savanas. Portanto, a dinâmica da fase lacunar não pode ser considerada como fator causal para a origem da alta diversidade de espécies, na fauna amazônica de vertebrados. $O$ papel da dinâmica fluvial como fator para a separação espacial de populaçóes e ulterior especiação parece óbvio no caso de grupos invertebrados que habitam o interior de florestas pluviais, porém é menos certo 
cm relaçáo a animais vertebrados; esses últimos estando freqiientemente em amplo contacto nas regióes de cabeceiras, onde os rios deixam de ser barreiras (veja consideraçóes acima).

\subsection{Origem da riqueza em espécies}

A origem da elevada diversidade de espécies nos trópicos está provavelmente ligada aos ciclos de distúrbios causados pelos processos de Milankovitch através da história da Terra. A fragmentaçáo do habitat e do centro de origem de animais florestais e não-florestais durante ciclos climático-vegetacionais sucessivos conduziram á diferenciação de subespécies e espécies em refúgios durante períodos de isolamento geográfico. A teoria dos refúgios ressalta a diferenciação de faunas tropicais e extra-tropicais por surtos dirigidos por eventos de vicariância ambiental cíclica. Os ciclos de Milankovitch atuaram como eficiente "bomba de especiação", impulsionando os mecanismos de evolução orgânica. Todavia, muitas espécies também se tornaram extintas em "armadilhas de espécies" quando seus habitats retraíram-se a menos de certo tamanho mínimo, durante períodos ecologicamente desfavoráveis. Outras espécies permaneceram indiferenciadas. $O$ balanço do efeito dos mecanismos atuando como "bombas de espécies" e "armadilhas de espécies", respectivamente, determinou se a diversidade de espécies de um grupo de animais que habitam uma dada região aumentou ou diminuiu durante um determinado período geológico. É provavel que em muitos casos a extinção crescente e a geração de espécies tenham se compensado mutuamente e a diversidade de espécies tenha permanecido mais ou menos inalterada, não obstante a alta reposição faunística. $\mathrm{O}$ efeito das oscilações de Milankovitch também incluiu, naturalmente, (1) flutuaçóes de temperatura durante o Pleistoceno em montanhas tropicais, conduzindo à disjunção alternada e à continuidade de centros de origem animal, através de deslocamento vertical de suas respectivas zonas de habitat $\mathrm{e}$ (2) flutuaçóes no nível do mar em regiōes costeiras dos continentes, conduzindo à separaçáo temporária e reunião de certas ilhas e suas faunas.

Além do efeito das oscilacóes de Milankovitch, durante a história geológica da Terra, outros processos causaram a formaçáo de barreiras para diferentes grupos de animais, iniciando assim a especiação. São eles: (1) mudanças paleogeográficas na distribuição de terra e mar que ocorreram mais irregularmente e em marcha mais vagarosa do que os ciclos de Milankovitch; (2) mudanças climáticas ao longo do lado a sotavento de cadeias de montanhas crescentes causaram mudanças vegetacionais numa escala razoavelmente local; (3) separação e deriva 
continental seguindo uma sequiência hierárquica de eventos de vicariância, através da formaçáo de barreiras oceânicas mais ou menos permanentes; só raramente essas barreiras desapareceram de novo graças à colisão continental (e.g. India e Ásia no Eoceno) ou ao desenvolvimento de uma conexão vulcânica como a ponte de terra na Meso-América religando secundáriamente as Américas do Norte e do Sul no fim do Plioceno (cerca de 3 milhóes de anos atrás); (4) erosáo continuada de cadeias de montanhas e terras rasas, como os montes testemunhos (tepuis) da regiáo de fronteira entre Venezuela e Brasil (tratadas acima). Esses processos geológicos todavia, são todos mais ou menos especiais no sentido de ser improvável sua reversão numa época posterior. Para ser eficaz, a evolução através de especiaçáo alopátrica requer um mecanismo impulsionante previsivelmente reversível, da ordem de dezenas ou centenas de milhares de anos consistentes com as taxas de diversificaçăo biológica. Os ciclos de Milankovitch suprem exatamente tal mecanismo. Além disso, a transição entre florestas e savanas opera aparentemente no princípio limiar, de sorte que uma pequena mudança nas condiçóes climáticas pode resultar numa alteração maior na distribuiçáo desses tipos de vegetação, impulsionando, assim, um mecanismo de vicariância maior. Processos climáticos repousam, provavelmente, na raiz de boa parte da especiaçáo que ocorreu em tempo geológico, especialmente no domínio terrestre nos continentes e, possivelmente, também nas camadas marinhas superficiais.

Um fator adicional responsável pela origem da elevada riqueza tropical em espécies é a área de ambientes tropicais consideravelmente maior do que a extra-tropical, em conjunção com a simetria climática de ambos os lados do equador (Terborgh 1973, 1992), veja fig.4. A área entre sucessivos graus de latitude é maior próxima ao equador, onde os trópicos formam uma faixa contínua, nos hemisférios norte e sul, visto que as zonas temperadas do norte e do sul estáo separadas por milhares de quilômetros. Além disso, a temperatura média anual varia pouco com a latitude nas proximidades do equador até $25^{\circ}$ de latitude (onde o gradiente de temperatura global diminui sensivelmente). Por essas razões geográficas, os trópicos formam uma regiāo contínua enorme em ambos os lados do equador através de vastas áreas de terra firme. Como Terborgh (1992: 150) destacou: "Aqui nós temos um caráter tempoinvariável da geografia da Terra que prevê maiores oportunidades para a especiaçáo alopátrica ao redor do equador do que em latitudes maiores. Além disso, as taxas de extinção nos trópicos deveriam ser inferiores porque áreas muito grandes tendem a manter grandes populaçôes que são menos vulneráveis à extinçáo do que populaçóes pequenas." Como uma das conseqüências dos fatores geográficos acima, flutuaçóes cli- 

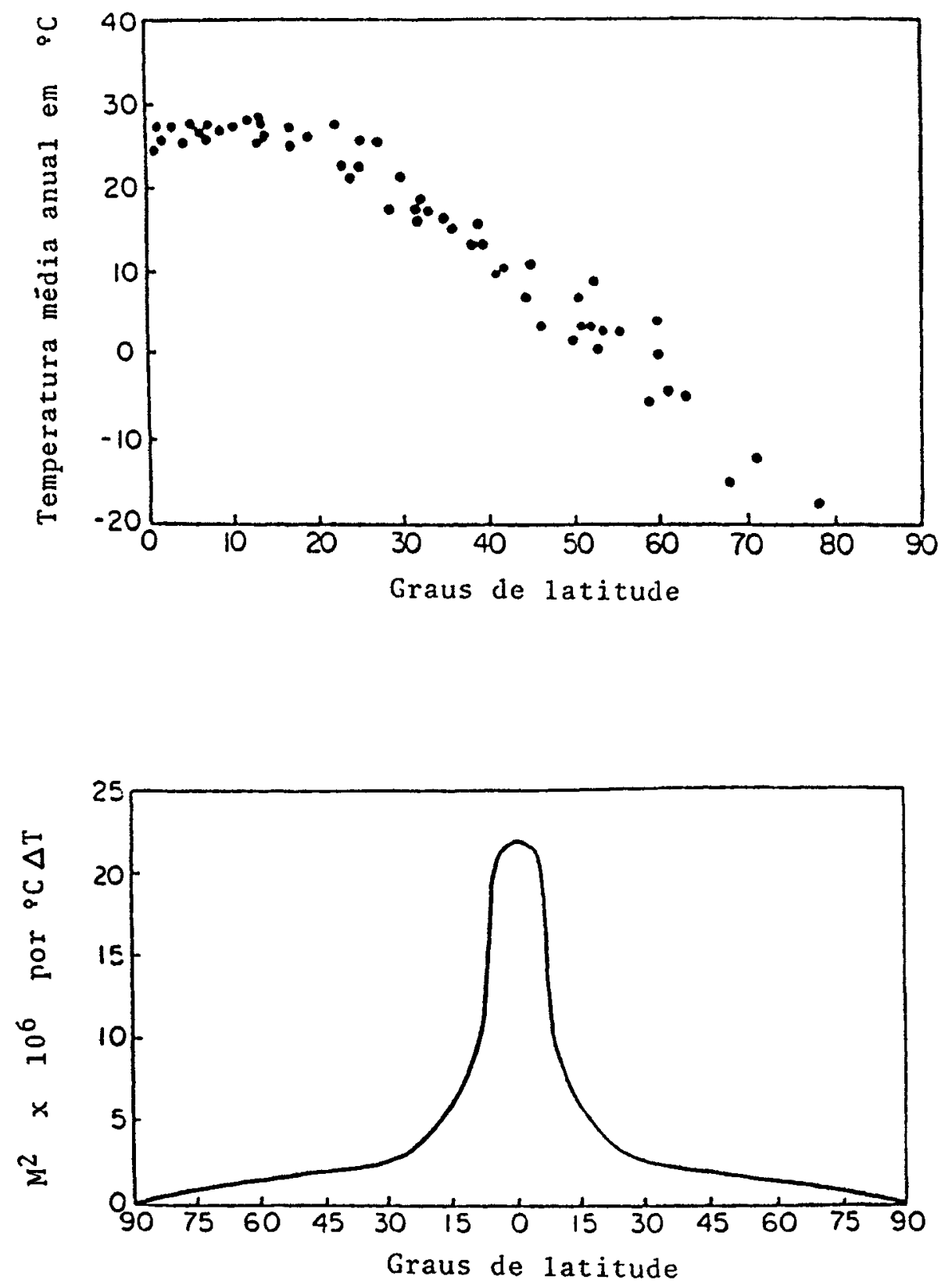

Fig. 4: Gradiente de temperatura global e área superficial. Encima, temperatura média anual de localidades continenciais de baixa elevação, decréscimo não perceptível do equador a uma latitude de cerca de 25 graus. Em latitudes superiores a temperatura média decresce uniformeménte até os pólos. Embaixo, a área da superfície da Terra entre isotermas de um grau centígrado de temperatura anual média decresce à medida que a latitude aumenta. A área de habitats disponíves para manter o processo de especiação é mais do que 10 vezes maior no equador do que em latitudes médias (segundo Terborgh, 1973, 1992). 
mático-vegetacionais globais geram mais fragmentos de habitats isolados (refúgios) durante cada uma das muitas reversóes nos trópicos do que nas zonas temperadas. Gerando um maior número de populaçóes isoladas (e, portanto, na média, mais espécies novas) por unidade de tempo geológico, a evoluçáo como fenômeno de indicador de tempo, processou-se mais rapidamente e mais efetivamente nos trópicos do que em latitudes maiores, embora o mecanismo de especiação, por si, é claro, tenha sempre se verificado de maneira idêntica nas faunas tropical $e$ extra-tropical do mundo.

\section{Observaçōes finais}

Depois de examinar dados da Amazônia, indicativos de alteraçóes vegetacionais em passado geológico recente, podemos formular a questão: "Quais são as diferenças entre os desmatamentos de hoje nos trópicos e o presumido desaparecimento de densa vegetação em certas áreas durante períodos climáticos secos do passado?" Entre muitas eu vejo as seguintes diferenças: (1) o desflorestamento, ao contrário da formação de refúgios no passado geológico, não está estritamente relacionado a gradientes climáticos, de sorte que é mais provável que o impacto seja de um tipo qualitativamente diferente; (2) o desflorestamento não é meramente uma retração como no passado, quando deixava refúgios extensivos intactos, mas um processo que conduz à fragmentaçáo desastrosa da paisagem inteira, numa escala geográfica pequena, com a extinção processando-se muito rapidamente em pequenas manchas isoladas de habitat; (3) o desflorestamento é também mais completo em grandes áreas dos trópicos do que no passado, quando florestas secas abertas e não savanas podem ter substituído florestas úmidas em grandes áreas e, (4) o desflorestamento ocorre mais rapidamente ("bruscamente" em linguagem geológica) sem nenhuma chance para o solo e a paisagem ajustarem-se. Todos os países tropicais estão fazendo esforços para preservar o máximo possível da riqueza em espécies tropicais criando reservas florestais e parques nacionais. Espera-se que as reservas sejam projetadas de tal maneira que, do ponto de vista biológico, áreas com importância biogeográfica particular sejam tratadas com prioridade: (1) áreas com riqueza máxima em espécies, (2) áreas onde se agrupam espécies localizadas (endêmicas), e, (3) áreas onde membros de pares de espécies e subespécies estejam em contacto secundário. Alguns desses aspectos biogeográficos foram considerados acima com respeito à avifauna da Amazônia. Espera-se que parte dos aspectos da fauna amazônica sejam preservados, não importando a interpretacáo de sua origem e história. 


\section{Agradecimentos}

Agradeço ao professor C. Pavan e à Fundação Memorial da América Latina, de Sâo Paulo, pelo convite para participar da "Conferência Amazônica", realizada em Sáo Paulo entre os dias 25 e 27 de março de 1992, onde apresentei este trabalho. Sou também grato pela oportunidade dos debates com o Dr. John Terborgh, Durham (Carolina do Norte, EUA) sobre vários aspectos das riquezas em espécies tropicais. O Dr. A. Hoppe (Friburgo, Alemanha) enviou-me, gentilmente, cópias de diversos estudos geológicos de depósitos pláceres na Amazônia.

\section{Sumário}

Ciclos de distúrbio ambiental, afetando a vegetaçáo da floresta pluvial, incluem dinâmica de curto prazo e de fase lacunar localizada, dinâmica fluvial e ciclos crescentes de longo prazo climático-vegetacionais regionais e ciclos tectônicos. Esses ciclos hierárquicos de distúrbio representam ciclos correntes de regeneraçáo da floresta pluvial. São cíclicos no sentido de uma seqüência repetitiva de alteraçóes. Todos os estágios dos ciclos de distúrbio são transitórios, isto é, nenhum representa uma fase "inicial" ou "final". Assim, esses processos são exemplos de ciclos de tempo sem um componente de direçáo. A dinâmica da fase lacunar de curto prazo e a dinâmica fluvial contribuem, efetivamente, para a heterogeneidade ambiental necessária à manutênçáo da elevada riqueza em espécies da Amazônia.

Flutuaçóes climático-vegetacionais de longo prazo têm conduzido à fragmentaçóes cíclicas de habitat em larga escala e à formação de refúgios ecológicos durante a maior parte da história da Terra. Essas flutuaçóes foram causadas por ciclos astronômicos de Milankovitch, com periodicidades de 20.000 a 100.000 anos, isto é, consistentes com as taxas de diversificação biológica. Os ciclos de Milankovitch provisionam evolução através de especiação alopátrica, com um mecanismo impulsionador reversível, previsível, que operou como "máquina de especiaçáo" ou "bomba de espécies", dignas de confiança, durante a maior parte da história geológica da Terra.

A área de ambientes tropicais consideravelmente maior do que a de extratropicais, em conjunção com a simetria climática de lado a lado do equador, explica o fato de que mais espécies originaram-se nos trópicos por unidade de tempo geológico. Nesse sentido a evolução ocor- 
reu mais rápida nos trópicos, embora o mecanismo de especiação em si tenha operado de maneira idêntica.

Organismos e espécies seguiram os indicadores de tempos de gencalogia ao longo das vias evolucionárias contingentes, impulsionadas por processos ambientais abióticos. A diferênciação evolucionária coloca esses processos ambientais cíclicos num contexto direcional.

\section{Referências bibliográficas}

Ab'Saber, A.N. 1982. The paleoclimate and paleoecology of Brazilian Amazonia, p. 41 59, in: Biological Diversification in the Tropics (ed. Prance, G.T.). Columbia Univ. Press, New York.

Absy, M.L., Cleef, A., Fournier, M., Martin, L., Servant, M., Sifeddine, A., Ferreira da Silva, M., Soubies, F., Suguio, K., Turcq, B. \& Van der Hammen, T. 1991. Mise en évidence de quatre phases d'overture da la fôret dense dans le sud-est de l'Amazonie au cours des 60.000 dernières années. Première comparaison avec d'autre régions tropicales. C.R. Acad. Sci. Paris, vol. 312, Serie II, p. 673 - 678.

Bartlein, P.J. \& Prentice, I.C. 1989. Orbital variations, climate and paleoecology. Trends in Ecology and Evolution (Tree) 4: 195 - 199.

Bennett, K.D. 1990. Milankovitch cycles and their effects on species in ecological and evolutionary time. Paleobiology 16: $11-21$.

Berger, A., Loutre, M.F. \& Dehant, V. 1989. Pre-Quaternary Milankovitch frequencies. Nature 342: 133.

Bettencourt, J.S., Muzzolon, R., Payolla, B.L., Dall'Tgna, L.G. \& Pinho, O.G. 1988. Depósitos estaníferos secundários de regiāo central de Rondônia, p. 217 - 241; in: Principais Depósitos Minerais do Brasil, vol. 3. Brasilia.

Bibus, E. 1983. Die klimamorphologische Bedeutung von stone-lines und decksedimenten in mehrgliedrigen Bodenprofilen Brasiliensis. Z. Geomorph. N.F., Suppl. - Band 48: $79-98$.

Bigarella, J.J. \& Ferreira, A.M.M. 1985. Amazonian geology and the Pleistocene and the Cenozoic environments and paleoclimates, p. 49 - 71, in: Amazonia. Key Environments (eds. Prance, G.T. \& Lovejoy, T.E.). Pergamon Press, Oxford.

Capparella, A.P. 1988. Genetic variation in neotropical birds: implications for the speciation process. Acta XIX Congr. Intern. Ornith. (Ottawa 1986), vol. II: 1658 - 1664.

Colinvaux, P. 1987. Amazon diversity in light of the paleoecological record. Quat. Sci. Rev. 6: 93 - 114 .

Colyn, M., Gautier-Hion, A. \& Verheyen, W. 1991. A re-appraisal of palaeoenvironmental history in central Africa: evidence for a major fluvial refuge in the Zaire Basin. J. Biogeogr. 18: $403-407$. 
Connor, E.F. 1986. The role of Pleistocene forest refugia in the evolution and biogeography of tropical biotas. Trends in Evolution and Ecology (Tree) 1: 165 - 168.

Connor, E.F. 1988. Digital representation in the analysis of biogeographic data. Acta XIX Congr. Intern. Ornith. (Ottawa 1986): 1019 - 1029.

Cracraft, J. \& Prum, R.O. 1988. Patterns and processes of diversification: Speciation and historical congruence in some neotropical birds. Evolution 42: 603-620.

Delcourt, H.R., Delcourt, P.A. \& Webb, T., III 1983. Dynamic plant ecology: the spectrum of vegetational change in space and time. Quat. Sci. Rev. 1: 153 - 175.

Di Castri, F. \& Hedley, M. 1988. Enhancing the credibility of ecology: interacting along and across hierarchical scales. GeoJournal 17: 5 - 35.

Eden, M.J., McGregor, D.F.M. \& Morelo, J.A. 1982. Geomorphology of the middle Caquetá basin of eastern Colombia. Z. Geomorph. N.F. 26: 343 - 364.

Emmerich, K.H. 1988. Relief, Böden und vegetation in Zentral und Nordwest-Brasilien unter besonderer Berücksichtigung der känozoischen Landschaftsentwicklung. Frankfurter Geowiss. Arbeiten, Ser. D (Phys. Geogr.) 8, 218p.

Fischer, A.G. 1981. Climatic oscillations in the biosphere, p. 103 - 131; in: Biotic Crises in Ecological and Evolutionary Time (ed. Nitecki, M.H.); Academic Press, New York.

Frailey, C.D., Lavinia, E.L., Rancy, A. \& Pereira de Souza, J. 1988. A proposed Pleistocene/Holocene lake in the Amazon Basin and its significance to Amazonian geology and biogeography. Acta Amazonica 18: 119 - 143.

Gentry, A.H. 1988. Tree species richness of upper Amazonian forests. Proc. Natl. Acad. Sci. USA 85: 156 - 159.

Gentry, A.H. 1989. Speciation in tropical forests, p.113 - 134, in: Tropical Forests. Botanical Dynamics, Speciation and Diversity (eds. Holm-Nielsen, L.B., Nielsen, I.C. and Balslev, H.). Academic Press, London.

Goldammer, J.G. \& Seibert, B. 1989. Natural rainforests fires in eastern Borneo during the Pleistocene and Holocene. Naturwiss. 76: 518 - 520.

Gould, S.J. 1987. Time's Arrow and Time's Cycles. Myth and Metaphor in the Discovery of Geological Time. Harvard Univ. Press, Massachusetts.

Haffer, J. 1967a. Speciation of Colombian forest birds west of the Andes. Amer. Mus. Novitates 2294,57 p.

Haffer, J. 1967b. Some allopatric species pairs of birds in northwestern Colombia. Auk 84: $343-365$.

Haffer, J. 1969. Speciation in Amazonian forest birds. Science 165: 131 - 137.

Haffer, J. 1974. Avian speciation in tropical South America. Publ. Nuttall Ornith. Club 14, $390 \mathrm{p}$. 
Haffer, J. 1985. Avian zoogeography of the neotropical lowlands. Ornith. Monogr. 36: $113-146$.

Haffer, J. 1987a. Quaternary history of Tropical America, p. 1 - 18; in: Biogeography and Quaternary History in Tropical America (eds. Whitmore, T.C. and Prance, G.T.), Clarendon Press, Oxford.

Haffer, J. 1987b. Biogeography of Neotropical birds, p.105 - 150; in Biogeography and Quaternary History of Tropical America. (eds. Whitmore, T.C. and Prance, G.T.), Clarendon Press, Oxford.

Haffer, J. 1990. Avian species richness in tropical South America. Studies on Neotropical Fauna and Environment 25; 157 - 183.

Haffer, J. 1991. Mosaic distribution patterns of neotropical forest birds and underlying cyclic disturbance processes, p. 83 - 105; in: The Mosaic-Cycle Concept of Ecosystems (ed. H. Remmert), Ecological Studies 85; Springer,Bcrlim.

Harrington, H.J. 1962. Paleogeographic development of South America. Bull. Amer. Assoc. Petrol. Geol. 46: 1773 - 1814.

Hartshorne, G.S. 1978. Tree falls and tropical forest dynamics, p. 617 - 638, in: Tropical Trees as Living Systems (eds. Tomlinson, P.B. and Zimmermann, M.H.), Cambridge Univ. Press, Cambridge.

Hartshorne, G.S. 1980. Neotropical forest dynamics. Biotropica 12 (Suppl.): 23 - 30.

Herbert, T.D. \& Fischer, A.G. 1986. Milankovitch climatic origin of inid-Cretaceous black shale rhythms in central Italy. Nature 321: $739-743$.

Hershkovitz, P. 1969. The Recent mammals of the Neotropical Region: a zoogeographic and ecological review. Quart. Rev. Biol. 44: 1 - 70.

Hershkovitz, P. 1977. Living New World Monkeys (Platyrrhini), vol. 1. Univ. Chicago Press, Chicago.

Hoppe, A. \& Schobbinghaus, C. 1991. Geologie und Bodenschätze Amazoniens. Zentralbl. Geol. Pal. Teil 1 p. 1787 - 1837.

Jornaux, A. 1975. Recherches géomorphologiques en Amazonie brésilienne. Bull. Centre Géomorph. Caen (CNRS) 20, 67p.

Kronberg, B.I., Benchimol, R.E. \& Bird, M.I. 1991. Geochemistry of Acre Subbasin sediments: Window on Ice-Age Amazonia. Interciencia 16: 138 - 141.

Levinton, J. 1988. Genetics, Paleontology, and Macroevolution. Cambridge Univ. Press, Cambridge.

Livingstone, D.A. 1980. History of the tropical rainforest. Paleobiology 6: $243-244$.

Lynch, J.D. 1988. Refugia, p. 311 - 342; in: Analytical Biogeography (eds. Myers, A.A. and Giller, P.S.). Chapman \& Hall, London. 
Mayr, E. 1942. Systematics and the Origin of Species from the Viewpoint of a Zoologist. Columbia Univ. Press, New York.

Mayr, E. 1963. Animal Species and Evolution. Harvard Univ. Press, Cambridge, Massachusetts.

Meave, J., Kellman, M., MacDougall, A. \& Rosales, J. 1991. Riparian habitats as tropical forest refugia. Global Ecology and Biogeography letters 1: $69-76$.

Müller, P. 1973. The Dispersal Centers of Terrestrial Vertebrates in the Neotropical Realm. Biogeographica 2. Junk, The Hague.

Olsen, P.E. 1986. A 40-million-year lake record of early Mesozoic orbital climatic forcing. Science 234: $842-848$.

Pickett, S.T.A., Kolasa, J. \& Collins, S.L. 1989. The ecological concept of disturbance and its expression at various hierarchical levels. Oikos 54: $129-136$.

Prance, G.T. (ed.) 1982. Biological Diversification in the Tropics. Columbia Univ. Press, New York.

Prance, G.T. \& Lovejoy, T.E. (eds.) 1985. Amazonia. Key Environments. Pergamon Press, Oxford.

Räsänen, M.E., Salo, J.S. \& Kalliola, R.J. 1987. Fluvial perturbance in the western Amazon basin: Regulation by longterm sub-Andean tectonics. Science 238: 1398 - 1401 .

Saldarriaga, J.G. \& West, D.C. 1986. Holocene fires in the northern Amazon basin. Quat. Research 26: 358 - 366.

Salo, J. 1987. Pleistocene refuges in the Amazon: evaluation of the biostratigraphical, lithostratigraphical and geomorphological data. Ann. Zool. Fenicci 24: 203 - 211.

Salo, J. \& Kalliola, R.J. 1989. River dynamics and natural forest regeneration in Peruvian Amazonia, in: Rainforest Regeneration and Management (ed. Jeffers, J.), MAB (UNESCO), Book ser., UNESCO and Cambridge Univ. Press, Cambridge.

Salo, J. \& Räsänen, M. 1989. Hierarchy of landscape patterns in western Amazonia, p. 35 - 45; in: Tropical Forest. Botanical Dynamics, Speciation and Diversity (eds. HolmNielsen, L.B., Nielsen, I.C. and Balslev, H.), Academic Press, London:

Salo, J., Kalliola, R., Häkkinen, I., Mäkinen, Y., Niemelä, P., Puhakka, M. \& Coley, P.D. 1986. River dynamics and the diversity of Amazon lowland forest. Nature 322: 254-358.

Sanford, R.L., Saldarriaga, J., Clark, K.E., Ulh, C. \& Herrera, R. 1985. Amazon rainforest fires. Science 227: 53-55.

Schubert, C. 1988. Climatic change during the last glacial maximum in northern South America and the Caribbean: a review. Interciencia 13: 128 - 137.

Simpson, B.B. \& Haffer, J. 1978. Speciation patterns in the Amazonian forest biota. Ann. Rev. Ecol. Syst. 9:497 - 518.

Terborgh, J. 1973. On the notion of favorableness in plant ecology. Amer. Nat. 107: 481 -501 . 
Terborgh, J. 1992. Diversity and the Tropical Rain Forest. Freeman \& Co., New York.

Tricart, J. 1974. Existence des périodes sèches au Quaternaire en Amazonie et dans les régions voisines. Rev. Géomorph. Dyn. 23: 145 - 158.

Tricart, J. 1975. Influence des oscillations climatiques récents sur le modèle en Amazonie orientale (région de Santarém) d'apres les images radar lateral. Z. Geomorpl. N.F. 19: 140 - 163.

Tricart, J. 1985. Evidence of Upper Pleistocene dry climate in northern South America, p. 197 - 217; in: Environmental Change and Tropical Geomorphology (eds. Douglas,I. and Spencer), Allen \& Unwin, London.

Urban, D.L., ON Neil, R.V. \& Schugart Jr., H.H. 1987. Landscape ecology. BioScience 37: $119-127$.

Vanzolini, P. 1967. Problems and programs in Amazonian zoology. Atas Simp. sobre a Biota Amazônica 5 (Zoologia): 85-95.

Vanzolini, P. 1970. Zoologia sistemática, geografia e a origem das espécies. Inst. Geográfico São Paulo. Série Teses e Monografias 3, 56p.

Vanzolini, P. 1973. Paleoclimates, relief, and species multiplication in tropical forests, p. 255 - 258; in: Tropical Forest Ecosystems in Africa and South America: a Comparative Review (eds. Meggers, B.J., Ayensu, E.S. and Duckworth, W.D.), Smithsonian Inst. Press, Washington.

Vanzolini, P. \& Ab'Saber, A.N. 1968. Divergence rate in South American lizards of the genus Liolnemus (Sauria, Iguanidae). Pap. Avulsos Zool., São Paulo, 21: 205 - 208.

Vanzolini, P. \& Williams, E.E. 1970. South American anoles: geographic differentiation and evolution of the Anolis chrysolepis species group (Sauria, Iguanidae). Arq. Zool. Săo Paulo, 19: 1 - 298.

Veiga, A.T.C., Dardenne, M.A. \& Salomão, E.P. 1988. Geologia dos aluviôes aurffcros e estanfferos da Amazônia. Anais XXXV Congr. Brasil. Geol. (Belém, Pará) 1: 164 177.

Vrba, E.S. 1985. Environment and evolution: Alrernative causes of the temporal distribution of evolutionary events. South Afr. J. Sci. 81: 229 - 236.

Whitmore, T.C. \& Prance, G.T. (eds.) 1987. Biogeography and Quaternary History in Tropical America. Oxford Monogr. on Biogeogr. 3. Clarendon Press, Oxford.

Jiurgen Haffer nasceu em Berlim, Alemanha, em 1932. Estudou geologia, paleontologia e biologia na Universidade de Göttingen, onde obteve o $\mathrm{PhD}$ em 1957. Assim que concluiu seus estudos, trabalhou como geologo em uma companhia internacional de petróleo nos campos da Colómbia e dos Estados Unidos (1957-1970) e como gerente de exploração no Irã, Egito, Noruega e Alemanha (1973-1988). Em 1988, com 55 anos, se aposentou e agora vive na Alemanha desenvolvendo projetos ornintológicos.

Conferência pronunciada no seminário internacional "Uma Estratégia Latino-Americana Para a Amazónia", em 27 de março de 1992, no auditório Simón Bolívar do Memorial da América Latina.

Tradução de Antonio Lamberti. O original em inglês - "Time's cycle and time's arrow in the history of Amazonia" - encontra-se à disposiçăo do lcitor no IEA para eventual consulta. 